Article

\title{
Proton Conductive Channel Optimization in Methanol Resistive Hybrid Hyperbranched Polyamide Proton Exchange Membrane
}

\author{
Liying Ma ${ }^{1,2} \mathbb{D}$, Jing $\mathrm{Li}^{2, *}$, Jie Xiong ${ }^{2,3}$, Guoxiao $\mathrm{Xu}^{2}$, Zhao $\mathrm{Liu}^{2}$ and Weiwei Cai ${ }^{2, *}$ \\ 1 School of Chemistry and Materials Science, Guizhou Normal University, 116 Baoshan North Road, \\ Guiyang 550001, China; maliying2018@163.com \\ 2 Sustainable Energy Laboratory, Faculty of Materials Science and Chemistry, \\ China University of Geosciences Wuhan, 388 Lumo RD, Wuhan 430074, China; \\ cumtbxiongjie@163.com (J.X.); guoxiao_xu123@163.com (G.X.); 15629023972@163.com (Z.L.) \\ 3 College of Chemistry, Chemical Engineering and Material Science, Zaozhuang University, \\ Zaozhuang 277160, China \\ * Correspondence: kinijing1984@gmail.com (J.L.); willcai1985@gmail.com (W.C.)
}

Received: 10 November 2017; Accepted: 8 December 2017; Published: 14 December 2017

\begin{abstract}
Based on a previously developed polyamide proton conductive macromolecule, the nano-scale structure of the self-assembled proton conductive channels (PCCs) is adjusted via enlarging the nano-scale pore size within the macromolecules. Hyperbranched polyamide macromolecules with different size are synthesized from different monomers to tune the nano-scale pore size within the macromolecules, and a series of hybrid membranes are prepared from these two micromoles to optimize the PCC structure in the proton exchange membrane. The optimized membrane exhibits methanol permeability low to $2.2 \times 10^{-7} \mathrm{~cm}^{2} / \mathrm{s}$, while the proton conductivity of the hybrid membrane can reach $0.25 \mathrm{~S} / \mathrm{cm}$ at $80^{\circ} \mathrm{C}$, which was much higher than the value of the Nafion 117 membrane $(0.192 \mathrm{~S} / \mathrm{cm})$. By considering the mechanical, dimensional, and the thermal properties, the hybrid hyperbranched polyamide proton exchange membrane (PEM) exhibits promising application potential in direct methanol fuel cells (DMFC).
\end{abstract}

Keywords: proton exchange membrane; methanol resistivity; direct methanol fuel cells; hybrid membrane

\section{Introduction}

Direct methanol fuel cells (DMFCs) are regarded as promising power sources for stationary, automotive, and portable electronic applications [1-6] attributed to the advantages, including facile fuel storage and utilization, mild operating temperature, and high energy density. Proton exchange membrane (PEM), which not only separates the fuel and oxidant, but also conducts protons from anode to cathode, is one of the most key components in a DMFC [7]. The perfluorinated sulfonic acidic Nafion membrane (DuPont) is the currently commercial proton exchange membrane for fuel cell applications, owing to the high proton conductivity under relatively low temperature, satisfied mechanical strength, and excellent oxidative stabilities. However, the high price and the high methanol permeability of the Nafion membrane are the major limitations that hinder the large scale commercial applications of DMFC technology [8-12]. It was reported that more than $40 \%$ of the methanol fuel was wasted through leaking crossover the Nafion membrane during the DMFC operation due to that the Nafion molecules with long side chains cannot be densely assembled [13,14]. The permeated methanol would be oxidized in the cathode catalyst layer, and hence, lower the power density of DMFC [15]. Therefore, many studies on alternative PEM material development were conducted to overcome the methanol 
permeation issue [16-19]. By considering the material cost simultaneously, great efforts have be made to develop high performance sulfonated aromatic polymers, such as poly(ether ether ketone) [20-22], poly(ether ketone) (PEK) [23,24], polybenzimidazole [25,26], and polyimide [27,28]. Zhang et al. [22] prepared a serial of sulfonated poly(ether ether ketone)s with pendant benzimidazole groups, the membranes exhibited satisfied mechanical and thermal stabilities, while the proton conductivity of the membranes was not ideal. Seo et al. [24] synthesized several PEKs and showed higher water uptake, IECs and thermal stability, while the proton conductivity of the membranes was still lower than that of Nafion 211.

Well-connected and highly ordered proton conductive channel (PCC) is considered to be the most key factor for high proton conductivity, strong mechanical property and low fuel permeability at the same time. To establish high efficient PCCs by controlling the alignment in the PEMs is therefore one of the most important tasks for novel PEM development [29]. Okamoto et al. [30] constructed well-connected PCCs in polyimide block copolymers, which was originated from hydrophobic and hydrophilic micro-phase separation by tuning the position of sulfonic acid groups on the polymer backbone or side-chain. These PEMs showed two times higher proton conductivity $(25 \mathrm{mS} / \mathrm{cm}$ at $30{ }^{\circ} \mathrm{C}$ and $50 \% \mathrm{RH}$ ) than the random analogs. Li et al. [31] synthesized triblock copolymers with in-situ formed well-connected PCCs for efficient proton conduction due to the nano-phase separation between the hydrophilic groups and the hydrophobic chain. The membrane exhibited high proton conductivity under reduced relative humidity conditions $(\mathrm{RH}=30-50 \%)$, superior antioxidative, and thermal stabilities. Another example is that the graft copolymers can possess higher proton conductivity and stronger mechanical strength than block copolymer due to the different degree of anisotropic PCCs in PEMs [32]. Guiver et al. [33] synthesized a comb-shaped graft polymer with densely sulfonated side-chains, and the densely sulfonated chains formed self-assemble nanoscale PCCs, resulting in a high proton conductivity $(100 \mathrm{mS} / \mathrm{cm}$ at $90 \% \mathrm{RH})$. Therefore, constructing the PCCs and controlling its orientation in PEMs to provide the effective transport route is an interesting and worth investigating area [34].

In our previous studies, we developed a hyperbranched PEMs with self-assembled hierarchical PCC (HPCC) for DMFC application [35,36]. The PEMs exhibited remarkably improved methanol-permeation resistant property and proton conductive property. The HPCC in the membrane is consisted of the first-order PCCs (FOPCCs) formed by the dense $-\mathrm{SO}_{3} \mathrm{H}$ within the $-\mathrm{COOH}$ end-capped macromolecules, and the second-order PCCs (SOPCCs) that were formed by the intermolecular hydrogen bonds among the $-\mathrm{COOH}$ groups.

Here, in this work, nano-structure of the FOPCCs in the PEM membrane are adjust to optimize the hyperbranched PEM performance via enlarging the nano-scale pore size within the macromolecules to improve the proton conductive efficiency. Polymer B in Figure 1 was therefore designed to replace polymer A. Since the membrane made from polymer B is fragile due to the rigidity from multiple benzene ring structure in the membrane, hybrid membranes with different weight ratio of polymer A to polymer B are fabricated. The optimized membrane exhibits a methanol permeability of low to $2.2 \times 10^{-7} \mathrm{~cm}^{2} / \mathrm{s}$. At the same time, the proton conductivity of the hybrid membrane of this work is as high as $0.25 \mathrm{~S} / \mathrm{cm}$ at $80^{\circ} \mathrm{C}$, much higher than the value of the Nafion 117 membrane $(0.192 \mathrm{~S} / \mathrm{cm})$ [36]. By considering the mechanical, dimensional, and the thermal properties, the hybrid hyperbranched polyamide PEM exhibits promising application potential in DMFC. 


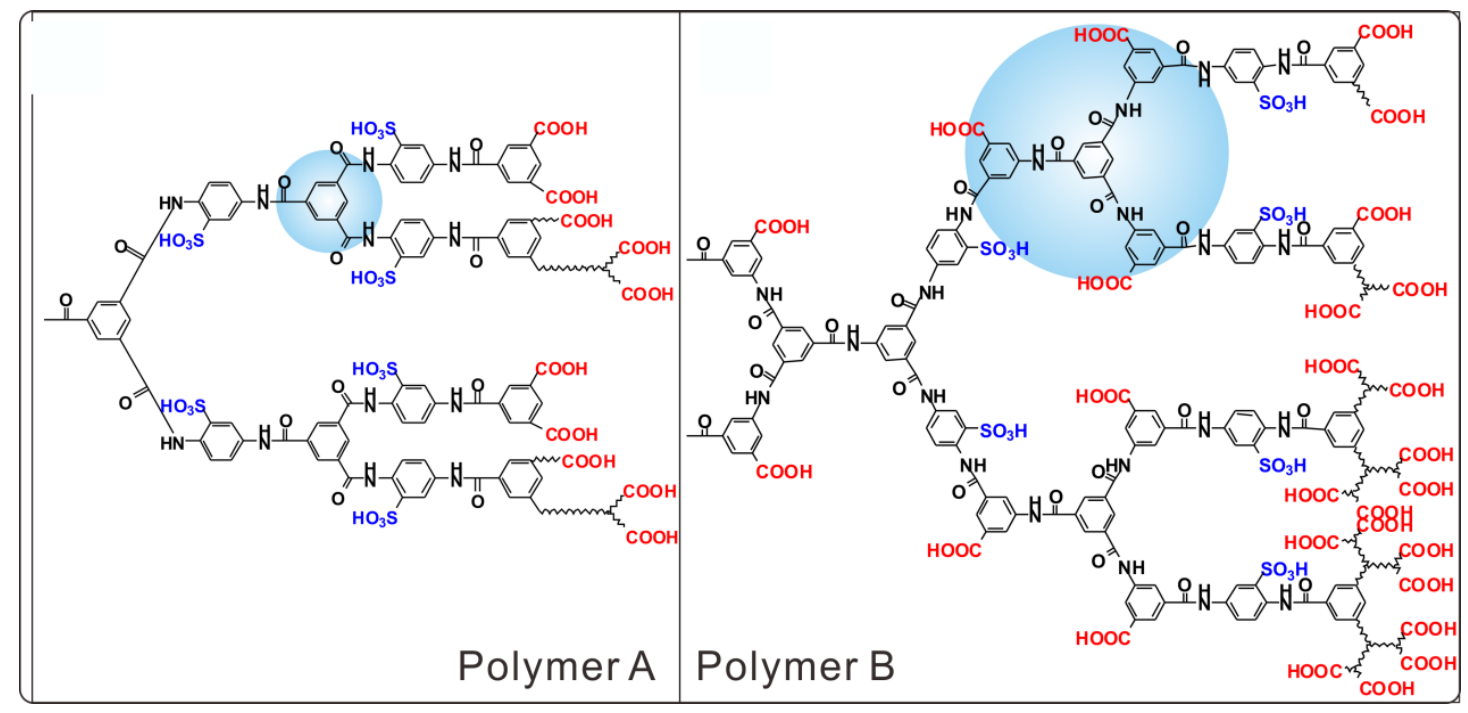

Figure 1. Chemical structure of polymer A and polymer B for first-order PCCs (FOPCC) optimization.

\section{Experimental}

\subsection{Materials}

Trimesic acid (TA), 2,4-diaminobenzenesulfonic acid (DSA), and Dimethyl 5-aminoisophthalate (DAP) were purchased from Adamas Reagent, Ltd., and dried at $80{ }^{\circ} \mathrm{C}$ for $24 \mathrm{~h}$ before using. N-Methyl-2-pyrrolidone (NMP), triphenylphosphosphite (TPP), and Pyridine (Py) were provided by Sinopharm Chemical Reagent Co., Ltd. and distilled from KOH. Nafion 117 was supplied by Dupont Co. (Wilmington, DE, USA).

\subsection{Synthesis}

\subsubsection{Polymer A}

TPP (1 mL), Py (3 mL), and NMP (4 mL) were added into a $50 \mathrm{~mL}$ two-necked round-bottom flask with TA ( $2 \mathrm{mmol}), \mathrm{LiCl}(0.32 \mathrm{~g})$ and p-DSA $(2 \mathrm{mmol})$. The mixture was maintained $100{ }^{\circ} \mathrm{C}$ for $2 \mathrm{~h}$ under argon atmosphere. Upon completion, the mixture was cooled to room temperature, and then washed with methanol and ultrapure water for several times. The product was dried at $80{ }^{\circ} \mathrm{C}$ under vacuum for $24 \mathrm{~h}$ (Scheme 1).

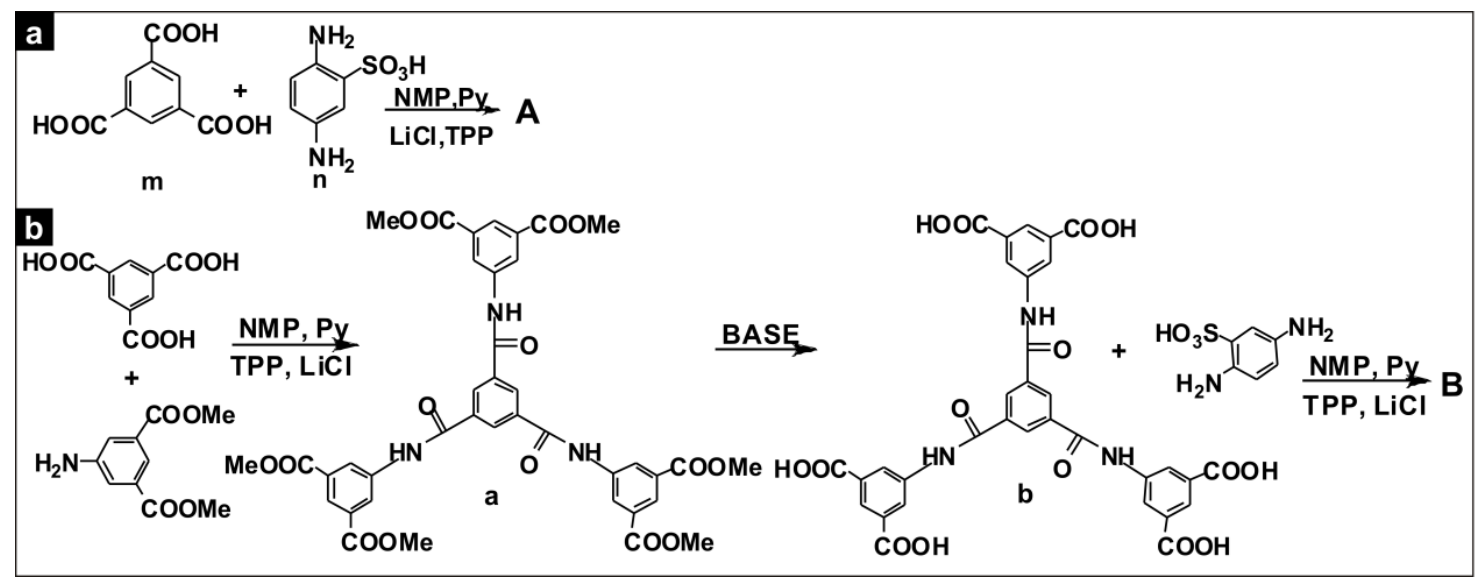

Scheme 1. Synthesis route of polymer A (a) and B (b). 


\subsubsection{Polymer B}

Synthesis of carboxylic ester (a): TA (10 mmol), DAP (20 mmol), TPP (5 mL), NMP (20 mL), and Py $(20 \mathrm{~mL})$ were added into a $100 \mathrm{~mL}$ two-necked round-bottom flask, and the reaction was maintained at $100{ }^{\circ} \mathrm{C}$ overnight. After cooling to RT, the resulting solution was poured into $100 \mathrm{~mL}$ methanol, filtered and washed with methanol and water, and then dried at $80^{\circ} \mathrm{C}$ for $24 \mathrm{~h}$ (Scheme 1).

Synthesis of carboxylic acid (b): carboxylic acid was synthesized by a basic hydrolysis reaction of product $a(5 \mathrm{mmol}), \mathrm{KOH}(30 \mathrm{mmol})$, and THF $(40 \mathrm{~mL})$ at room temperature for $1 \mathrm{~d}$. The clear liquid was acidized with hydrochloric acid till the $\mathrm{pH}=3$, and then the THF and water were removed from the reaction solution. The white powder was dried under vacuum at $80^{\circ} \mathrm{C}$ for $24 \mathrm{~h}$ (Scheme 1 ).

Synthesis of Polymer B: Product $b(2 \mathrm{mmol})$, p-DSA $(2 \mathrm{mmol}), \mathrm{LiCl}(0.32 \mathrm{~g}), \mathrm{TPP}(1 \mathrm{~mL})$, NMP $(4 \mathrm{~mL})$, and Py $(3 \mathrm{~mL})$ were added into a flask that was equipped with an argon inlet, magnetic stirrer, and water-cooled condenser. The reaction mixture was maintained at $100{ }^{\circ} \mathrm{C}$ for $3 \mathrm{~h}$. The viscous polymer was washed with methanol and water several times and dried at $80^{\circ} \mathrm{C}$ under vacuum for $24 \mathrm{~h}$ (Scheme 1).

For both Polymer A and Polymer B, the size of the hyperbranded macromolecules can be determined by precisely control the monomer ratio. At the same time, the successful - $\mathrm{COOH}$ end-capping of these two polymers can be achieved since the monomer with $-\mathrm{COOH}$ groups are slightly excessive.

\subsection{Membrane Preparation}

The hybrid membranes of ca. 100 um were prepared using solution casting technique. The polymer A and the polymer B were dissolved in dimethyl sulfoxide (DMSO) to form homogeneous solution at about $80^{\circ} \mathrm{C}$, respectively. Then, the hybrid solution of polymer $\mathrm{A}$ and polymer $\mathrm{B}$ were filtered and cast on a Petri dish and evaporated the solvent at $80^{\circ} \mathrm{C}$ to give a uniform hybrid membrane. $\mathrm{AB}-x$ membranes with $x$ as the weight percentage of the polymer $\mathrm{A}$ in the hybrid membranes $(x=80$, $85,90,95)$. The membranes were immersed in $1 \mathrm{M} \mathrm{HCl}$ solution for acid form by ion exchange at RT for $12 \mathrm{~h}$, and then washed with water until the $\mathrm{pH}$ of the solutions reached $\mathrm{pH}=7$.

\subsection{Measurements and Characterizations}

${ }^{1} \mathrm{H}$ NMR spectra were carried out using a Bruker AVANCE III HD instrument (400 MHz) in DMSO- $d_{6}$ as solvent and TMS as the internal standard. The polymers structure was recorded on a FT-IR Nicolet6700 spectrometer. The atomic force microscopy (AFM) images of the hybrid membranes were carried out using a Digital Instruments Multimode (SPM9700, Shimadzu, Kyoto, Japan). The cross-section images of the hybrid membranes were obtained from a scanning electron microscopy (SEM, SU8010, Hitachi, Tokyo, Japan). The thermogravimetric analysis (TGA) of membranes was performed with a NetzschSTA 409 PC TG-DTA instrument (Netzsch, Bavaria, Germany) in the temperature range from $30{ }^{\circ} \mathrm{C}$ to $600{ }^{\circ} \mathrm{C}$, at $10{ }^{\circ} \mathrm{C} / \mathrm{min}$ under a nitrogen atmosphere. Proton conductivity of the hybrid membranes was performed by four-electrode AC impendence method using an Interface 1000 electrochemical workstation (Gamry, Warminster, PA, USA). The membrane $(1 \mathrm{~cm} \times 3 \mathrm{~cm})$ was placed in the test cell and measured in the temperature range of $25-80{ }^{\circ} \mathrm{C}$ at $100 \% \mathrm{RH}$. The proton conductivity was calculated from the following equation:

$$
\sigma=\frac{d}{R t w}
$$

where $\sigma$ is the proton conductivity in the transverse direction of the membranes $(\mathrm{S} / \mathrm{cm}), w$ and $t$ are the membrane width $(\mathrm{cm})$ and thickness $(\mathrm{cm})$, respectively. $d$ is the distance between the two electrodes $(\mathrm{cm}) . R$ is the measured resistance of the membrane $(\Omega)$.

Ion exchange capacity (IEC) of the membranes was determined by a classical acid-base titration. Membrane sample was immersed in $1 \mathrm{M} \mathrm{NaCl}$ solution for $48 \mathrm{~h}$ to replace the $\mathrm{H}^{+}$ions with $\mathrm{Na}^{+}$ions. 
The exchange proton $\mathrm{H}^{+}$in the solution was titrated using $0.01 \mathrm{M} \mathrm{NaOH}$, with phenolphthalein as an indicator. The IEC was calculated by the equation as follows:

$$
\mathrm{IEC}=\frac{\mathrm{V} \times \mathrm{C}}{\mathrm{W}}(\mathrm{mmol} / \mathrm{g})
$$

where $\mathrm{C}$ is the concentration of the $0.01 \mathrm{M} \mathrm{NaOH}$ solution (mol/L), $\mathrm{V}$ and $\mathrm{W}$ is the volume of the $0.01 \mathrm{M} \mathrm{NaOH}$ solution $(\mathrm{mL})$ and the weight of dry membrane $(\mathrm{g})$, respectively.

A piece of membrane sample was immersed in deionized water at room temperature for $12 \mathrm{~h}$, and then removed the surface water with tissue paper and recorded the weight and the volume quickly. The membrane was then dried at $80^{\circ} \mathrm{C}$ for $12 \mathrm{~h}$ to remove the residual solvent or water and quickly recorded the weight and the volume. Water uptake and volume swelling of the membranes was calculated by the following equation:

$$
\mathrm{WU}=\frac{\left(\mathrm{W}_{\mathrm{Wet}}-\mathrm{W}_{\mathrm{dry}}\right)}{\mathrm{W}_{\mathrm{dry}}} \times 100 \%
$$

where $W_{\text {dry }}$ and $W_{\text {wet }}$ are the weights of dry and wet membranes, respectively.

$$
\mathrm{VS}=\frac{\mathrm{V}_{\mathrm{Wet}}-\mathrm{V}_{\mathrm{dry}}}{\mathrm{V}_{\mathrm{dry}}} \times 100 \%
$$

where $V_{\text {dry }}$ and $V_{\text {wet }}$ are the volumes of the corresponding dry and wet membranes, respectively.

The methanol permeability of membranes was measured by using an " $\mathrm{H}$ " type diaphragm diffusion with two cells separated by the membrane. One cell contained $1 \mathrm{M}$ methanol solution and the other contained deionized water with magnetic stirrer for methanol diffusion. The methanol concentration in the water side of the diffusion cell was measured by using a gas chromatograph (9790II Zhejiang Fuli Analytical Instruments Co., Ltd., Wenling, China). The methanol permeability was determined according to the following equation:

$$
p=\frac{1}{\mathrm{~A}} \times \frac{\mathrm{V}_{\mathrm{B}}}{\mathrm{C}_{\mathrm{A}}} \times \frac{\Delta \mathrm{C}}{\Delta \mathrm{t}}
$$

where $p$ is the methanol permeability $\left(\mathrm{cm}^{2} / \mathrm{s}\right), 1$ and $\mathrm{A}$ is the thickness and the effective diffusion area, respectively. $V_{B}$ is the volume of the compartment $\left(\mathrm{cm}^{3}\right), C_{A}$ is the initial concentration of methanol $\left(\mathrm{mol} / \mathrm{cm}^{3}\right) . \Delta \mathrm{C}$ and $\Delta \mathrm{t}$ are methanol concentration of the methanol solution $\left(\mathrm{mol} / \mathrm{cm}^{3}\right)$ and the diffusion time (s), respectively.

Strain-tensile cuves of the hybrid membranes and Nafion membrane (water soaked) were recorded using Labthink XLW (PC) at a strain rate of $25 \mathrm{~mm} / \mathrm{min}$ with a $50 \mathrm{~N}$ load cell.

\section{Results and Discussion}

Polymer structure of polymer A and polymer B was confirmed by ${ }^{1} \mathrm{H}$ NMR and FT-IR spectra in Figures 2 and 3, respectively. For polymer A, ${ }^{1} \mathrm{H}$ NMR $\left(400 \mathrm{MHz}, \mathrm{DMSO}-\mathrm{d}_{6}\right)$, the distinct resonance at $11.8 \mathrm{ppm}$ and $10.9 \mathrm{ppm}$ presented the $-\mathrm{COOH}$ and the $-\mathrm{CONH}$-group, respectively. For the precursor a, the signals of hydrogen $(\mathrm{Ha})$ are assigned to the $-\mathrm{CONH}-$, the signals of hydrogen atoms $\left(\mathrm{H}_{\mathrm{b}-\mathrm{d}}\right)$ are attributed to the phenyl group, and the signals of hydrogen $\left(\mathrm{H}_{\mathrm{e}}\right)$ are assigned to methyl group. For the precursor $b,{ }^{1} \mathrm{H}$ NMR $\left(400 \mathrm{MHz}, \mathrm{DMSO}^{-\mathrm{d}_{6}}\right) \delta 11.3,10.9,8.9,8.8,8.3$ ascribing to the hydrogen atom on the molecule marked by "a", "b", "c", "d", and "e", respectively. For polymer B, the signals at $11.1 \mathrm{ppm}$ presented the end-capped group - $\mathrm{COOH}$ of polymer. 


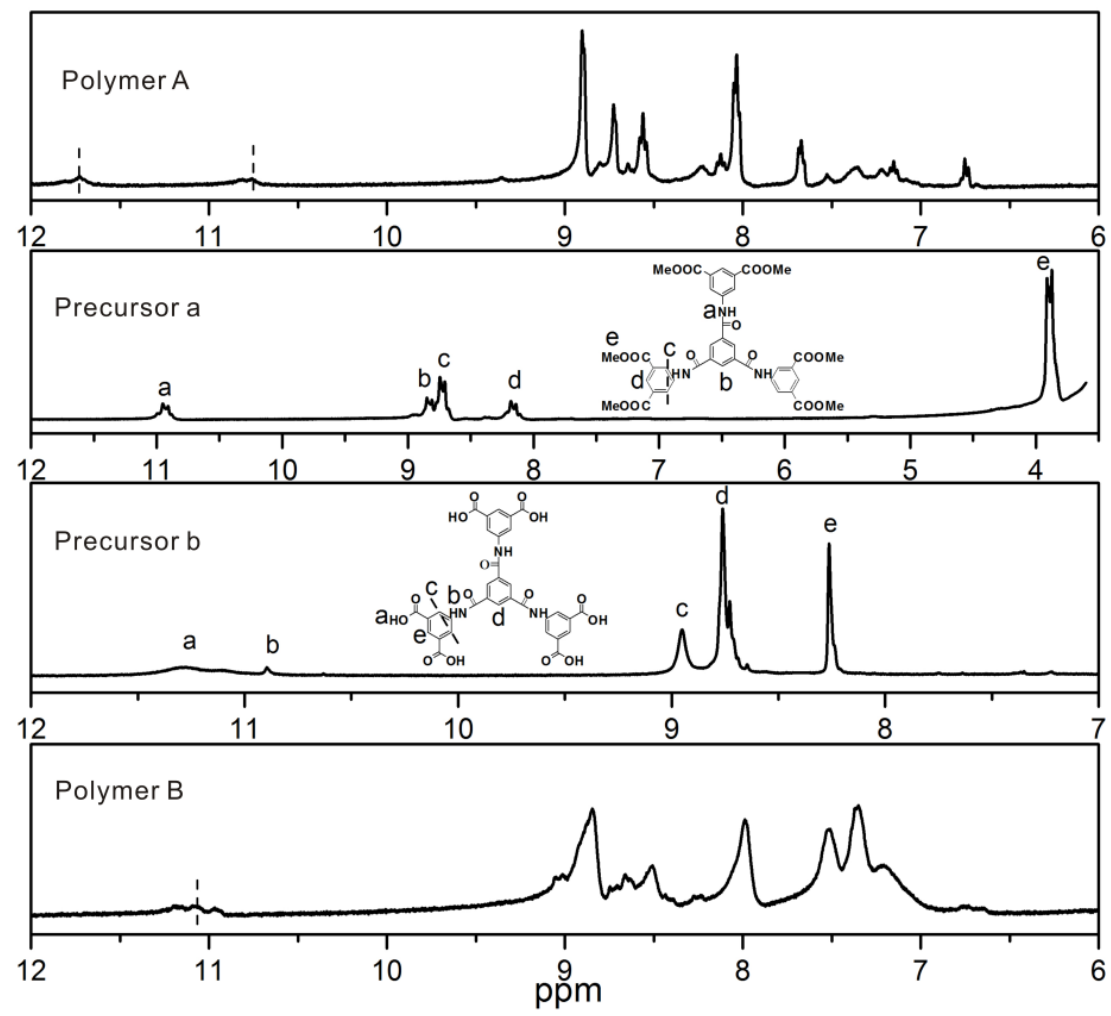

Figure 2. ${ }^{1} \mathrm{H}$ NMR spectra of precursor $a$ and $b$, Polymer A and polymer B.

For polymer A (Figure 3a), the FT-IR spectrum depicted the $\mathrm{C}=\mathrm{O}$ stretching bands at about $1700 \mathrm{~cm}^{-1}$ and $\mathrm{O}-\mathrm{H}$ bending vibrations at $945 \mathrm{~cm}^{-1}$ in $-\mathrm{COOH}$ of polymer A. For precursor $a$ (Figure 3b), the peak at $2952 \mathrm{~cm}^{-1}$ are assigned to the amide group, the 1725 and $1681 \mathrm{~cm}^{-1}$ indicate the presence of the $\mathrm{C}=\mathrm{O}$ of carboxyl and amide, respectively. The peak at $1551 \mathrm{~cm}^{-1}$ is attributed to the $\mathrm{N}-\mathrm{H}$ bending vibrations, and $1343 \mathrm{~cm}^{-1}$ are assigned to the $\mathrm{C}-\mathrm{N}$ stretching vibrations. For precursor $\mathrm{b}$ (Figure 3c), $3079 \mathrm{~cm}^{-1}\left(v_{\mathrm{OH}},-\mathrm{COOH}\right), 1710 \mathrm{~cm}^{-1}\left(v_{\mathrm{C}=\mathrm{O}},-\mathrm{CONH}\right)$, and $1556 \mathrm{~cm}^{-1}\left(v_{\mathrm{C}=\mathrm{O}},-\mathrm{COOH}\right)$. For polymer $B$ (Figure $3 \mathrm{~d}$ ), the band at $1735 \mathrm{~cm}^{-1}$ and $952 \mathrm{~cm}^{-1}$ indicated the presence of the $\mathrm{C}=\mathrm{O}$ stretching vibration and $\mathrm{O}-\mathrm{H}$ bending vibration, respectively.

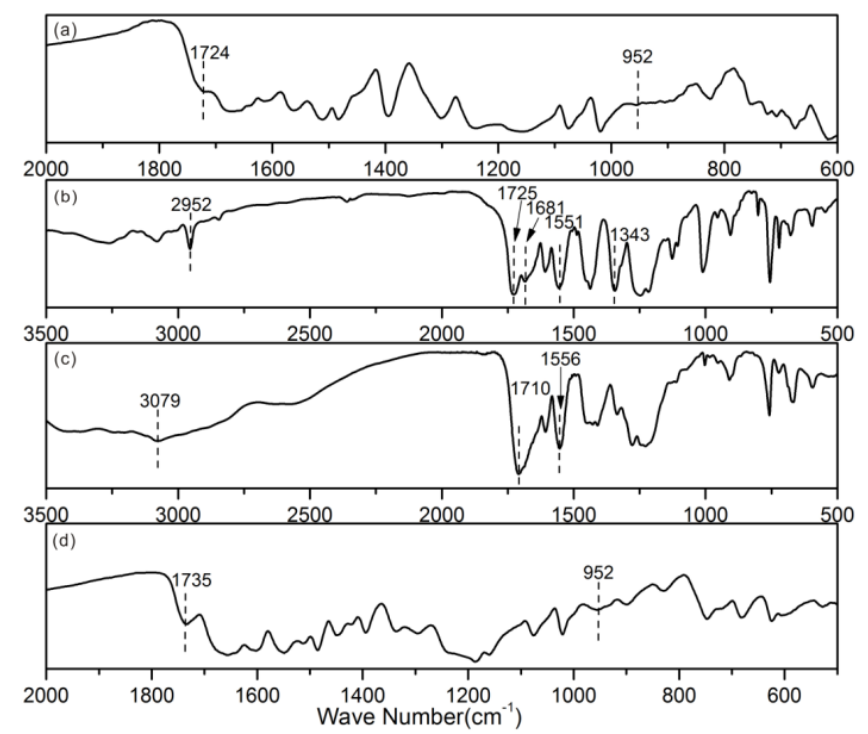

Figure 3. FT-IR spectra of (a) Polymer A; (b) precursor $a$; (c) precursor $b$; and (d) Polymer B. 
Methanol permeability is the key descriptor of a PEM for DMFC application. Methanol permeability through the hybrid membranes are compared in Figure 4a. The hybrid membrane exhibited methanol permeability in the range of $2.20 \times 10^{-7} \mathrm{~cm}^{2} / \mathrm{s}$ to $3.78 \times 10^{-7} \mathrm{~cm}^{2} / \mathrm{s}$, more than 1.5 times lower than that of CC-100 membrane made from polymer A. Apparently, with the polymer B weight ratio ranging from 0 to $20 \%$, the methanol permeability diminished from $4.86 \times 10^{-7}$ to $2.20 \times 10^{-7} \mathrm{~cm}^{2} / \mathrm{s}$, attributed to the well-connected network resulting from hydrogen bonding of abundant $-\mathrm{SO}_{3} \mathrm{H}$ group and end-capped - $\mathrm{COOH}$ group in polymer $\mathrm{A}$ and B. The well-connected network effectively prevented methanol permeation, Figure $4 b, c$ illustrated the scanning electron microscope morphologies (SEM) of the cross-section of CC-80 and CC-95 hybrid membranes, which showed a flat and uniform topography resulting in effective resistance on methanol permeation.
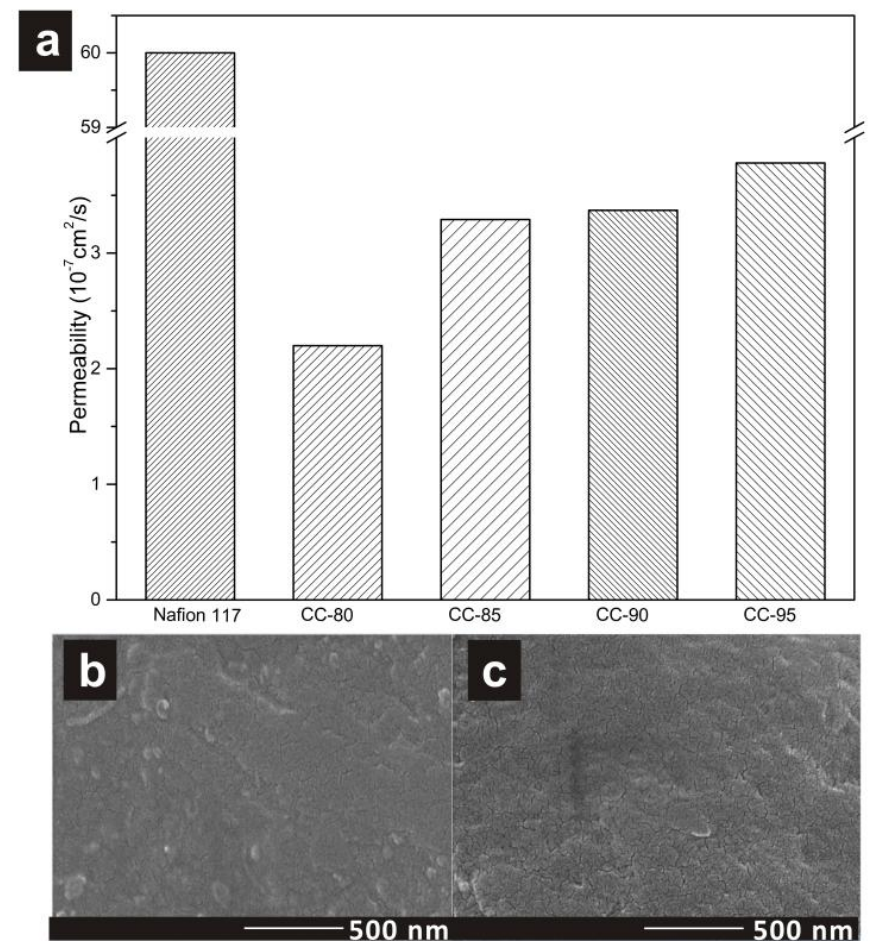

Figure 4. The methanol permeability through the hybrid membranes (a) and the cross-section SEM images of the CC-80 (b) and CC-95 (c) hybrid membranes.

Proton conductivity is considered as the most important coefficient to evaluate a PEM. Displayed in Figure 5 are temperature dependency curves of proton conductivity for the four hybrid membranes and the Nafion 117 membrane. It can be found that the CC-90 and CC-95 hybrid membranes exhibited superior proton conductive property than the Nafion 117 membrane in the entire studied temperature range. The CC-85 displayed comparative proton conductivity with that of Nafion 117 membrane. The proton conductivity of the CC-95 membrane is high to $0.132 \mathrm{~S} / \mathrm{cm}$ and $0.255 \mathrm{~S} / \mathrm{cm}$ at $30{ }^{\circ} \mathrm{C}$ and $80{ }^{\circ} \mathrm{C}$, respectively. The great proton conductivity of the CC- 95 membrane agrees well with the high measured IEC value, as provided in Table 1 . With the increasing ratio of polymer A from $80 \%$ to $95 \%$, the IEC value of the hybrid membranes increased from 1.52 to $1.93 \mathrm{mmol} / \mathrm{g}$. At the same, proton conductivity of the hybrid membrane may also relate to the micro phase-separation structure of the membranes. As compared in Figure 5b,c, the AFM tapping mode phase image of the CC-95 hybrid membrane with the best proton conductive performance exhibited more remarkable hydrophilic/hydrophobic phase-separation than the CC-80 hybrid membrane did.

By considering proton conductive and methanol-permeation resistive properties at the same time, the selectivity of the hybrid membranes are calculated according to the equation $s=\sigma / p$, where $\sigma$ 
and $p$ are proton conductivity and methanol permeability of the membrane, respectively. It can be found from Table 1 That all the four hybrid membranes showed higher selectivity than pristine CC-100 membrane, primarily due to the depressed methanol permeation. Among the four hybrid membranes, the CC-95 membrane exhibited the greatest selectivity, and is therefore considered as the optimized CC-x hybrid membrane for DMFC application. Selectivity of the CC-95 membranes is $34.92 \times 10^{4} \mathrm{~S} \cdot \mathrm{s} / \mathrm{cm}^{3}$, ca. 1.5 times higher than that of the CC-100 membrane.
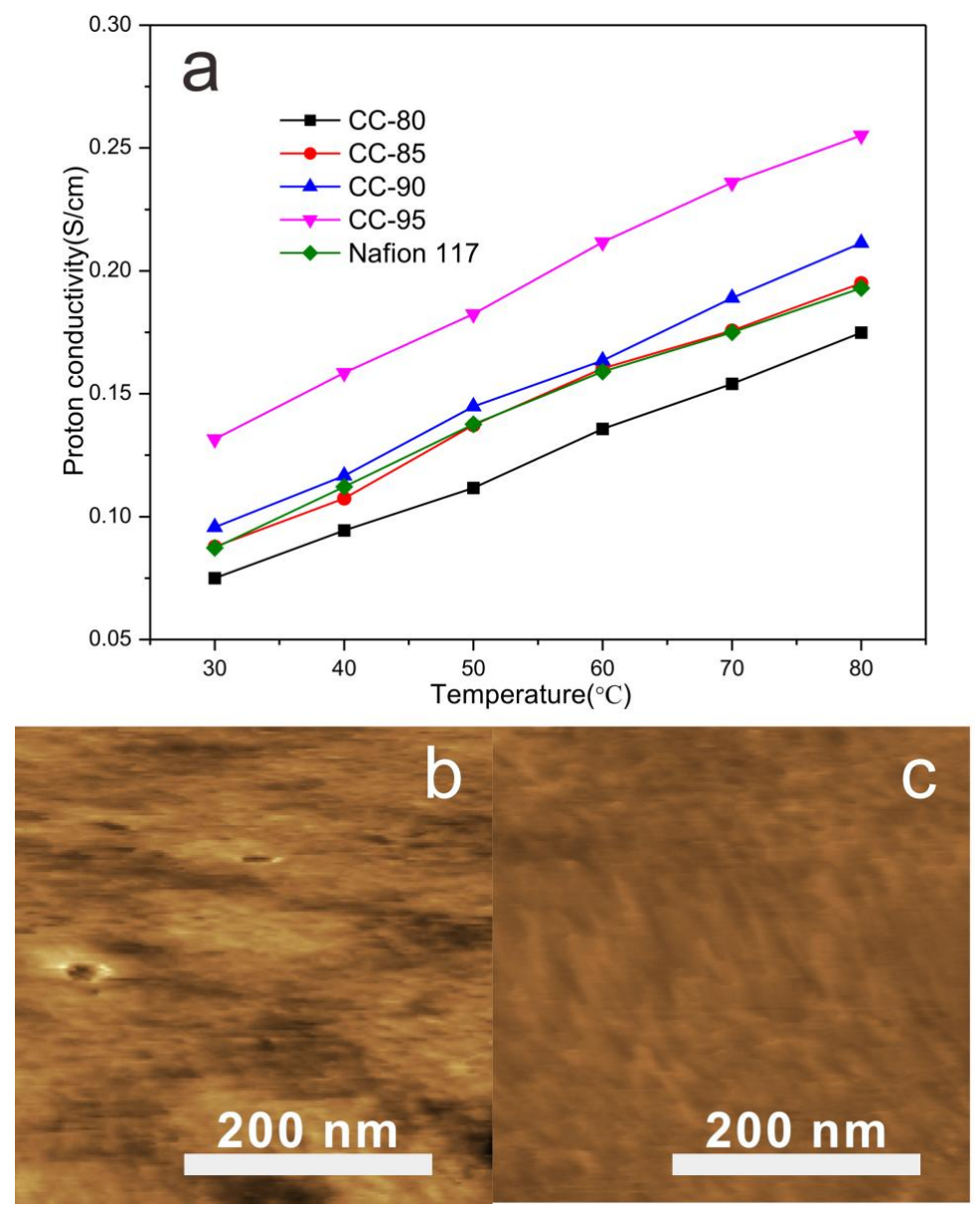

Figure 5. (a) Temperature dependences of proton conductivity of the hybrid membranes and Nafion 117; the AFM tapping images of the (b) CC-80 and (c) CC-95 hybrid membranes.

Table 1. Ion exchange capacity (IEC), water uptake, volume swelling, methanol permeability and selectivity of hybrid membranes.

\begin{tabular}{cccccc}
\hline Membranes & CC-80 & CC-85 & CC-90 & CC-95 & CC-100 \\
\hline Water uptake $(\%)$ & 37.56 & 36.27 & 35.25 & 33.52 & 31.71 \\
Volume swelling $(\%)$ & 34.95 & 32.02 & 31.19 & 30.41 & 27.48 \\
Permeability $\left(10^{-7} \mathrm{~cm}^{2} / \mathrm{s}\right)$ & 2.20 & 3.29 & 3.37 & 3.78 & 4.86 \\
IEC $(\mathrm{mmol} / \mathrm{g})$ & 1.5243 & 1.7293 & 1.8905 & 1.9263 & 2.33 \\
Proton conductivity $\left(\mathrm{S} / \mathrm{cm}^{3} 30^{\circ} \mathrm{C}\right)$ & 0.075 & 0.088 & 0.096 & 0.132 & 0.113 \\
Selectivity $\left(10^{4} \mathrm{~S} \cdot \mathrm{s} / \mathrm{cm}^{3}\right)$ & 34.09 & 26.75 & 28.49 & 34.92 & 23.25 \\
\hline
\end{tabular}

Before the practical application in DMFC, dimensional, mechanical, and thermal stabilities of the hybrid membranes have to be evaluated. The water uptake and volume swelling of the hybrid membranes were therefore measured and compared in Table 1. It can be found that the volume swelling of the hybrid membranes diminished with an increasing amount of polymer A due to the decreased 
water uptake ratio. Whatever, all of the hybrid membranes exhibited a smaller volume swelling ratio value than the water uptake value, indicating great dimensional stability of the hybrid membranes.

Strong mechanical property of the membrane is one of the important demands to withstand high compression for MEA fabrication of PEMFC and DMFC applications [37]. The hybrid membranes exhibited good mechanical property from the stress-strain plots, as shown as displayed in Figure 6a. The hybrid membranes exhibited high tensile stress of 18-22 MPa, which can be comparable to that of Nafion 117 (20 MPa). Enhanced tensile stress of the hybrid membranes is attributed to from the hydrogen bonding interaction between the end-capped - $\mathrm{COOH}$ groups of macromolecules and the multi-benzene ring structure of polymer B. Good thermal stability of the hybrid membranes was also proved by the TGA analysis (Figure 6b). The hybrid membranes exhibited three-step weight loss thermograms in the TGA analysis. The first weight loss of the hybrid membranes at about $100{ }^{\circ} \mathrm{C}$ is attributed to the evaporation of absorbed water and solvent. The second between $250{ }^{\circ} \mathrm{C}$ and $300{ }^{\circ} \mathrm{C}$ was caused by the degradation of the sulfonic acid groups within the membranes. The third was seen at above $550{ }^{\circ} \mathrm{C}$ due to the degradation of the polymer main chain [38]. In conclusion, all the three prepared exhibited satisfied mechanical and thermal stabilities for fuel cell applications.
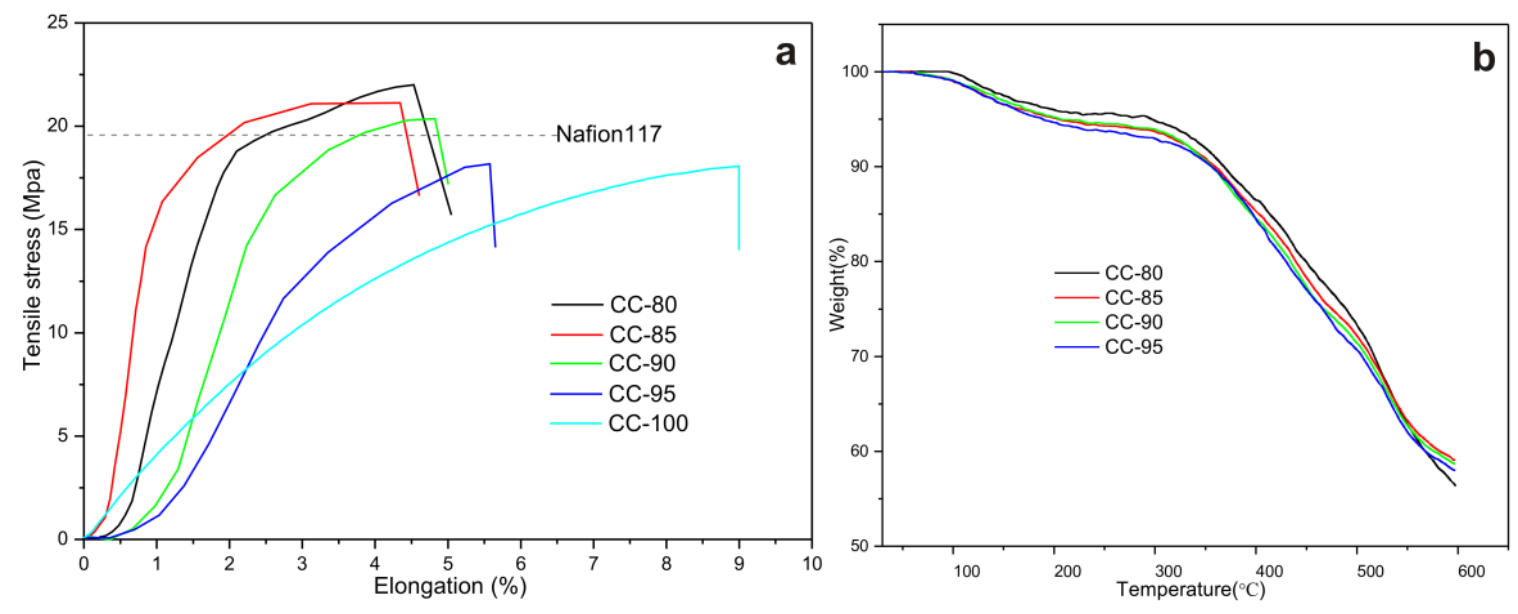

Figure 6. The stress-strain relationship (a) and the thermogravimetric analysis (TGA) curves (b) of the hybrid membranes.

\section{Conclusions}

Two - $\mathrm{COOH}$ end-capped hyperbranched polymers were successfully synthesized and hybrid proton exchange membranes were prepared from them with different ratios. The obtained hybrid membrane exhibited great proton conductivity, strong mechanical property, low methanol permeability, and satisfied thermal stability for DMFC application. The optimized hybrid membrane exhibited a methanol permeability of $3.78 \times 10^{-7} \mathrm{~cm}^{2} / \mathrm{s}$, which is ca. 15 times lower than that of the Nafion 117 membrane. At the same time, the proton conductivity of this optimized membrane was $0.255 \mathrm{~S} / \mathrm{cm}$ at $80^{\circ} \mathrm{C}$, which is also much greater than that of the commercial Nafion 117 membrane $(0.193 \mathrm{~S} / \mathrm{cm}$ at $80^{\circ} \mathrm{C}$ ). Above all, with satisfied thermal and mechanical stabilities, the prepared hybrid membrane showed promising potential for application in DMFCs.

Acknowledgments: This work is supported by the National Natural Science Foundation of China (Nos. 21503197 and 21703211), Fundamental Research Funds for the Central University, China University of Geosciences (Wuhan) (Nos. CUG150615 and CUG150627) and Guizhou science and technology fund (Nos. [2015]2007).

Author Contributions: Weiwei Cai, Jing Li and Liying Ma conceived and designed the experiments; Liying Ma and Guoxiao Xu performed the experiments; Liying Ma and Jie Xiong analyzed the data; Weiwei Cai, Liying Ma and Zhao Liu wrote the paper.

Conflicts of Interest: There are no conflicts to declare. 


\section{References}

1. Rikukawa, M.; Sanui, K. Proton-conducting polymer electrolyte membranes based on hydrocarbon polymers. Prog. Polym. Sci. 2000, 25, 1463-1502. [CrossRef]

2. Hickner, M.A.; Ghassemi, H.; Kim, Y.S.; Einsla, B.R.; McGrath, J.E. Alternative polymer systems for proton exchange membranes (PEMs). Chem. Rev. 2004, 104, 4587-4611. [CrossRef] [PubMed]

3. Neburchilov, V.; Martin, J.; Wang, H.; Zhang, J. A review of polymer electrolyte membranes for direct methanol fuel cells. J. Power Sources 2007, 169, 221-238. [CrossRef]

4. Ahmed, M.; Dincer, I. A review on methanol crossover in direct methanol fuel cells: Challenges and achievements. Int. J. Energy Res. 2011, 35, 1213-1228. [CrossRef]

5. Lufrano, F.; Baglio, V.; Staiti, P.; Antonucci, V.; Arico, A.S. Performance analysis of polymer electrolyte membranes for direct methanol fuel cells. J. Power Sources 2013, 243, 519-534. [CrossRef]

6. Li, X.; Faghri, A. Review and advances of direct methanol fuel cells (DMFCs) part I: Design, fabrication, and testing with high concentration methanol solutions. J. Power Sources 2013, 226, 223-240. [CrossRef]

7. Peighambardoust, S.J.; Rowshanzamir, S.; Amjadi, M. Review of the proton exchange membranes for fuel cell applications. Int. J. Hydrog. Energy 2010, 35, 9349-9384. [CrossRef]

8. Kerres, J.A. Development of ionomer membranes for fuel cells. J. Membr. Sci. 2001, 185, 3-27. [CrossRef]

9. Higashihara, T.; Matsumoto, K.; Ueda, M. Sulfonated aromatic hydrocarbon polymers as proton exchange membranes for fuel cells. Polymer 2009, 50, 5341-5357. [CrossRef]

10. Inzelt, G.; Pineri, M.; Schultze, J.; Vorotyntsev, M. Electron and proton conducting polymers: Recent developments and prospects. Electrochim. Acta 2000, 45, 2403-2421. [CrossRef]

11. Chikashige, Y.; Chikyu, Y.; Miyatake, K.; Watanabe, M. Poly(arylene ether) Ionomers Containing Sulfofluorenyl Groups for Fuel Cell Applications. Macromolecules 2005, 38, 7121-7126. [CrossRef]

12. Cho, E.; Park, J.-S.; Sekhon, S.S.; Park, G.-G.; Yang, T.-H.; Lee, W.-Y.; Kim, C.-S.; Park, S.-B. A Study on Proton Conductivity of Composite Membranes with Various Ionic Liquids for High-Temperature Anhydrous Fuel Cells. J. Electrochem. Soc. 2009, 156, B197-B202. [CrossRef]

13. Beattie, P.D.; Orfino, F.P.; Basura, V.I.; Zychowska, K.; Ding, J.; Chuy, C.; Schmeisser, J.; Holdcroft, S. Ionic conductivity of proton exchange membranes. J. Electroanal. Chem. 2001, 503, 45-56. [CrossRef]

14. Ansari, S.; Kelarakis, A.; Estevez, L.; Giannelis, E.P. Oriented arrays of graphene in a polymer matrix by in situ reduction of graphite oxide nanosheets. Small 2010, 6, 205-209. [CrossRef] [PubMed]

15. Ramya, K.; Dhathathreyan, K.S. Direct methanol fuel cells: Determination of fuel crossover in a polymer electrolyte membrane. J. Electroanal. Chem. 2003, 542, 109-115. [CrossRef]

16. Hu, Z.; Yin, Y.; Yaguchi, K.; Endo, N.; Higa, M.; Okamoto, K.-I. Synthesis and properties of sulfonated multiblock copolynaphthalimides. Polymer 2009, 50, 2933-2943. [CrossRef]

17. Wu, L.; Huang, C.; Woo, J.-J.; Wu, D.; Yun, S.-H.; Seo, S.-J.; Xu, T.; Moon, S.-H. Hydrogen Bonding: A Channel for Protons to Transfer through Acid-Base Pairs. J. Phys. Chem. B 2009, 113, 12265-12270. [CrossRef] [PubMed]

18. Wu, L.; Huang, C.; Woo, J.-J.; Wu, D.; Yun, S.-H.; Seo, S.-J.; Xu, T.; Moon, S.-H. Modifying a Proton Conductive Membrane by Embedding a "Barrier". J. Phys. Chem. B 2010, 114, 13121-13127. [CrossRef] [PubMed]

19. Cho, C.G.; Kim, Y.S.; Yu, X.; Hill, M.; McGrath, J.E. Synthesis and Characterization of Poly(arylene ether sulfone) Copolymers with Sulfonimide Side Groups for a Proton-Exchange Membrane. J. Polym. Sci. 2006, 44, 6007-6014. [CrossRef]

20. Carbone, A.; Pedicini, R.; Portale, G.; Longo, A.; D’Ilario, L.; Passalacqua, E. Sulphonated poly(ether ether ketone) membranes for fuel cell application: Thermal and structural characterisation. J. Power Sources 2006, 163, 18-26. [CrossRef]

21. Abouzari-Lotf, E.; Nasef, M.M.; Ghassemi, H.; Zakeri, M.; Ahmad, A.; Abdollahi, Y. Improved Methanol Barrier Property of Nafion Hybrid Membrane by Incorporating Nanofibrous Inter layer Self-Immobilized with High Level of Phosphotungstic Acid. ACS Appl. Mat. Interfaces 2015, 7, 17008-17015. [CrossRef] [PubMed]

22. Gong, F.; Li, N.; Zhang, S. Synthesis and properties of novel sulfonated poly(phenylquinoxaline)s as proton exchange membranes. Polymer 2009, 50, 6001-6008. [CrossRef]

23. Kreuer, K.D. On the development of proton conducting polymer membranes for hydrogen and methanol fuel cells. J. Membr. Sci. 2001, 185, 29-39. [CrossRef] 
24. Choi, B.G.; Huh, Y.S.; Park, Y.C.; Jung, D.H.; Hong, W.H.; Park, H. Enhanced transport properties in polymer electrolyte composite membranes with graphene oxide sheets. Carbon 2012, 50, 5395-5402. [CrossRef]

25. Wycisk, R.; Lee, J.K.; Pintauro, P.N. Sulfonated polyphosphazene-polybenzimidazole membranes for DMFCs. J. Electrochem. Soc. 2005, 152, A892-A898. [CrossRef]

26. Abdelkareem, M.A.; Morohashi, N.; Nakagawa, N. Factors affecting methanol transport in a passive DMFC employing a porous carbon plate. J. Power Sources 2007, 172, 659-665. [CrossRef]

27. Miyatake, K.; Zhou, H.; Watanabe, M. Proton Conductive Polyimide Electrolytes Containing Fluorenyl Groups: Synthesis, Properties, and Branching Effect. Macromolecules 2004, 37, 4956-4960. [CrossRef]

28. Borup, R.; Meyers, J.; Pivovar, B.; Kim, Y.S.; Mukundan, R.; Garland, N.; Myers, D.; Wilson, M.; Garzon, F.; Wood, D.; et al. Scientific aspects of polymer electrolyte fuel cell durability and degradation. Chem. Rev. 2007, 107, 3904-3951. [CrossRef] [PubMed]

29. Cui, Y.; Baker, A.P.; Xu, X.; Xiang, Y.; Wang, L.; Lavorgna, M.; Wu, J. Enhancement of Nafion based membranes for direct methanol fuel cell applications through the inclusion of ammonium-X zeolite fillers. J. Power Sources 2015, 294, 369-376. [CrossRef]

30. Cote, L.J.; Kim, F.; Huang, J. Langmuir-Blodgett Assembly of Graphite Oxide Single Layers. J. Am. Chem. Soc. 2008, 131, 1043-1049. [CrossRef] [PubMed]

31. Li, N.; Lee, S.Y.; Liu, Y.-L.; Lee, Y.M.; Guiver, M.D. A new class of highly-conducting polymer electrolyte membranes: Aromatic ABA triblock copolymers. Energy Environ. Sci. 2012, 5, 5346-5355. [CrossRef]

32. Tsang, E.M.W.; Zhang, Z.; Shi, Z.; Soboleva, T.; Holdcroft, S. Considerations of Macromolecular Structure in the Design of Proton Conducting Polymer Membranes: Graft versus Diblock Polyelectrolytes. J. Am. Chem. Soc. 2007, 129, 15106-15107. [CrossRef] [PubMed]

33. Li, N.; Wang, C.; Lee, S.Y.; Park, C.H.; Lee, Y.M.; Guiver, M.D. Enhancement of Proton Transport by Nanochannels in Comb-Shaped Copoly(arylene ether sulfone)s. Angew. Chem. Int. Ed. 2011, 50, 9158-9161. [CrossRef] [PubMed]

34. Ahmad, H.; Kamarudin, S.K.; Hasran, U.A.; Daud, W.R.W. Overview of hybrid membranes for direct-methanol fuel-cell applications. Int. J. Hydrog. Energy 2010, 35, 2160-2175. [CrossRef]

35. Ma, L.; Cai, W.; Li, J.; Fan, K.; Jiang, Y.; Ma, L.; Cheng, H. A high performance polyamide-based proton exchange membrane fabricated via construction of hierarchical proton conductive channels. J. Power Source 2016, 302, 189-194. [CrossRef]

36. Ma, L.; Li, J.; Cai, W.; Fan, K.; Jiang, Y.; Cheng, H. A facile method to construct highly efficient methanol resistive polyamide-based proton exchange membrane. Int. J. Hydrog. Energy 2016, 41, 16205-16211. [CrossRef]

37. Ansari, Y.; Tucker, T.G.; Huang, W.; Klein, I.S.; Lee, S.Y.; Yarger, J.L.; Angell, C.A. A flexible all-inorganic fuel cell membrane with conductivity above Nafion, and durable operation at $150{ }^{\circ}$ C. J. Power Sources 2016, 303, 142-149. [CrossRef]

38. Yeager, H.L. Cation and Water Diffusion in Nafion Ion Exchange Membranes: Influence of Polymer Structure. J. Electrochem. Soc. 1981, 128, 1880-1884. [CrossRef]

(C) 2017 by the authors. Licensee MDPI, Basel, Switzerland. This article is an open access article distributed under the terms and conditions of the Creative Commons Attribution (CC BY) license (http://creativecommons.org/licenses/by/4.0/). 